\title{
ПРИМЕНА НА АНАЛИЗАТА НА СОДРЖИНА ВО ПЕДАГОШКИТЕ ИСТРАЖУВАҢА И ПРАКТИКА
}

\section{Кратка содржина}

Анализата на содржина е една од најстарите и најчесто применувани истражувачки техники во општествените истражувань и педагогијата, техника која има исклучително значене и придонес за развојот на педагошката наука и практика. Во почетокот на нејзината примена се настојувало оваа техника да има квантитативен карактер, а подоцна се развива и како квалитативна истражувачка техника која служи за откриване на скриените, силболички значена на содржината во одреден контекст.

Во современото значене и облик, анализата на содржина има голем потенцијал за примена во проучуване на педагошките феномени, но и за примена во секојдневната воспитно-образовна работа во училиштето и вонучилишните активности.

Во конкретното истражуване, анализата на содржина е применета во наставата по Македонски јазик во првите два образовни изиклуси од основното воспитание и образование. Предмет на анализа се лектирните дела кои се предвидени по овој наставен предмет, што вклучува лектири од домашни и странски автори со различна жанровска и родовска припадност.

Резултатите нудат квантитативни показатели за процентуалната застапеност на одделните видови лектирни дела и квалититативна анализа во однос на нивната содржина, воспитните и емоционални потенцијали и етичкото влијание врз учениците.

Клучни зборови: АНАЯИЗА НА СОДРЖИНА, ИСТРАЖУВАЧКА ТЕХНИКА, ЛЕКТИРНИ ДЕЛА, ПЕДАГОГИЈА

\section{Вовед}

Анализата на содржина е една од најстарите истражувачки техники. Кога станува збор за примена во истражувања со квалитативен карактер, анадизата на содржина се раздикува од онаа класичната што се користи во квантитативните истражувања. Класичната анализа настојува со помош на квантитативни показатели да ја презентира содржината на еден вербален, неквантитативен документ и потоа системски да изведе закдучоци. Од тие причини, анализата на содржина од ваков вид може да се вброи во групата на објективни, квантитативни техники. Во подоцнежните истражувања, 
анализата на содржина се применува и како типична квалитативна техника со која покрај очигледните, манифестни карактеристики на документите се настојува да се откријат и скриените, симбодички значења на текстот, мотивите на авторот, како и контекстот во кој настанало едно дело. Во современата анализа на содржина не се бележи само зачестеноста на фразите или зборовите во еден документ, туку се оди подлабоко и се настојува да се разбере значењето на пораката што тој текст ја содржи.

Освен во научните педагошки истражувања, анализата на содржина може да биде применета и во наставни цели и да ја унапреди работата на наставниците, педагозите, воспитувачите.

\section{Анадизата на содржина како истражувачка техника}

Анализата на содржина првенствено се развила како техника за анадиза на комуникацијата, при што се користела за проучување на содржината на подитичките документи, а нешто подоцна за вреднување на новинарските написи. Берелсон, анализата на содржина ја дефинира како техника на истражување чија задача е да даде „објективен, системски и квантитативен опис на очигледната содржина на комуникацијата.” (Берелсон, 1995). Класиците на анализата на содржина (Lasswell, Lazarsfeld, Berelson) сметале дека со инсистирањето на нејзината квантификација ќе ја направат оваа техника пообјективна. Во современите определби на анализата на содржина, не само што не се инсистира на нејзината квантитативна природа, туку и нејзиниот предмет се поместува од очигледните содржини на документите кон поскриените, симбодички значења што тие ги носат. Покрај видливото, манифестното, пораките најчесто имаат и латентно, преносно значење. За да може тоа да се открие потребно е да се воочи врската на пораката со средината, односно контекстот во кој таа настанала. На пример, Крипендорф (1981) ја дава следнава дефиниција: „Анализата на содржина е истражувачка техника за изведување повторливи и редијабилни заклучоци од содржината и нејзиниот контекст" (според Гредељ, 1986). Според тоа, анализата на содржина може да се сфати како квалитативна техника која ги проучува скриените, симболички значења на пораките врз основа на контекстот во кој тие настанале. Наместо самите документи како предмет на анализа, во овој случај се обидуваме да дознаеме нешто и за оној што нив ги создал, за неговите особини, цели и мотиви тие пораки да бидат напишани. Некои методолози ваквата техника ја нарекуваат контекстуална анализа.

Анализата на содржина има големи можности за примена во проучувањето на општествени и педагошки проблеми и како самостојна и како помошна истражувачка техника. Со неа може компаративно да се проучуваат целите на воспитанието и образованието, да се анализираат наставните планови и програми, да се вреднуваат учебниците од раздични аспекти, да се вреднуваат концептите и содржините на учењето, да се 
истражуваат ставовите на субјектите на наставата, комуникацијата, однесувањето на учениците, да се анализираат историографски документи значајни за развојот на образованието и воспитанието, да се прават портрети на значајни дичности од педагошката историја, да се истражуваат вредностите на содржините на прирачната литература, на лектирните изданија, да се открива нивната идеодошка и подитичка обоеност итн.

\section{Примена на анадизата на содржина во педагошките истражувања- метододошки специфики}

Анализата на содржината е една од најчесто применетите техники во педагошките истражувања. Скоро да не постои истражување во образованието каде анализата на содржината не е неопходна за доагање до релевантни податоци преку анадиза на дневници, белешки, табеларни прегледи, писмени подготовки, педагошка и друга документација.

Првите обиди за формализирање на анализата на содржина, односно инсистирање таа да се одвива по претходно утврдени барања, биле направени во областа на комуникацијата. Основата на секоја човекова комуникација ја чини содржината која може да ја дефинираме како збир на пораки изразени на раздичен начин и со раздични симболи: зборови, формули, музика, графички, ликовно, тридимензионално. За да можат да се проучат сите компоненти на човековата комуникација, а посебно да се разбере пораката која „испраќачот” ја праќа на „примачот”, требало да се пронајде начин како да се анадизира содржината на таквата комуникација. Кога анализата на содржина е претворена во истражувачка техника, поставени се сосема одредени методолошки барања.

Основна цел на секоја анализа на содржина како истражувачка техника е да се дојде до објективни податоци и факти релевантни за предметот на проучување. Тие факти се содржани во разновидни извори. Тоа се во суштина документи во кои фактите можат да бидат забележани, искажани или сочувани на раздичен начин. Документите (изворите) на факти можат да бидат: пишани извори, фотографии, цртежи, слики, филмови, радиозаписи и други аудиоизвори, телевизиски и видеозаписи, информатичко-компјутерски записи, тридимензионални средства (простор, згради, опрема, мебел, средства за работа и забава). Раздични се симболите со кои се забележани фактите во тие извори (од обични пишани, преку математички, музички, компјутерски, ликовни, па до ритмички, изразот на лице, начин на однесување и слично).

Кога станува збор за педагогијата и воспитанието, тогаш како посебни категории на документи, чија содржина се анализира во процесот на педагошките истражувања, може да се наведат следниве: службена документација, закони, правилници, статути и акти од областа на образованието, училишна документација, документација на вонучилишни институции значајни за образование на деца и возрасни, лична документација 
на стручните дица значајни за воспитување деца, портфолио на учениците, педагошки дела, фотографии од истакнати педагози, видеозаписи од педагошката практика, тридимензионални средства од учидниците и занималните, инструменти што се користат во педагошките истражувања и разни други документи од педагошката теорија и практика.

Наведената документација може да се однесува на минатото, на одреден период, одредени видови институции или поединци, а може да се однесува и на сегашноста. Во зависност од видот на изворот, фактите во таа документација може да бидат запишани на раздичен начин и да имаат квантитативен или квалитативен карактер.

Изворите на факти кои ја сочинуваат документацијата за обработка може да бидат примарни, кога се настанати непосредно во процесот на воспитание и образование, на пример, во училиштата иди во вонучилишните институции. Тоа се изворни и оригинални документи за воспитно-образовниот процес и за субјектите кои во него учествувале, за условите во кои се одвивало воспитанието итн. Педагошките истражувања кои ги користат примарните извори на факти се пообјективни и секогаш кога тоа е можно, треба да настојуваме да дојдеме до примарни податоци. Постојат ситуации кога не постои можност да се дојде до примарни извори на податоци и во тој случај се користат секундарни, терцијарни и други извори. Секундарните извори на факти ги преземаме од веќе реализирани истражувања, особено кога станува збор за појави кои се проучувани во минатото или од истражувачи од други географски региони.

Текот по кој се одвива анадизата на содржина е сличен со општиот тек на педагошките проучувања и истражувања, со одредени специфичности кои произдегуваат од оваа истражувачка техника.

Кога истражувачот го избрал предметот на истражување, ги формулирал целта, задачите и хипотезите и кога е утврден временскиот период на проучувањето, тој се наоѓа пред задача да утврди во кои документи постојат релевантни факти за предметот на проучување и каде тие извори на факти се наоѓаат. Најнапред се прави диста на сите достапни извори. Составувањето на таквата листа на извори не е едноставно и лесно. Понекогаш е потребно многу долго да се трага по некои документи и извори. Во овој процес, истражувачот може да консултира: педагошки библиографии, каталози во библиотеки, архивски материјали, каталози и збирки од музеи, дигитални бази на податоци, интервјуирање и неформални разговори со поединци.

Кога е составен списокот на пронајдени извори, а пред да се пристапи кон анализа на содржината на тие извори, потребно е да се изврши критичка оценка за вредноста на изворите. Тоа значи да се одреди дали изворите се оригинални и автентични, дали навистина настанале во процесот на воспитно-образовната дејност, дади се однесуваат на избраниот временски период во согласност со предметот на истражување, кој е автор на тие документи, во какви околности тие настанале. Тоа се нарекува екстерна 
критика иди проверка на документите. По оваа надворешна проверка на документот, се преминува на интерна критика, односно утврдување дали податоците кои ги содржи еден извор се точни, потполни, објективни и непристрасни. Фактите од еден извор се споредуваат со фактите од други извори и се утврдува дали се исти или раздични.

Во текот на истражувањето во кое се користи техниката анадиза на содржината и кое се потпира на факти од повеќе разновидни извори, истражувачот треба да изврши категоризација на изворите. Не е доводно само да се утврди дали изворите се примарни или секундарни, туку треба и да се утврди дали тие се значајни, важни, репрезентативни, целосни и потполни.

За да може да се изврши анализа на содржината на селектираните извори, истражувачот мора јасно да ја дефинира единицуата за анализа на содржина. Тој мора да утврди прецизно што сака да открие во одбраните извори, што е тоа што треба да се идентификува и забележи како факт во процесот на анализа на содржината кај еден извор.

Ако има повеќе видови единици за анадиза на содржина, истражувачот мора да утврди критериум за нивно класифицирање и средување. Тоа подразбира да се утврдат и категориите според даден критериум, во кои ќе се класифицираат сите собрани единици.

На крај, пред да се започне со реализирање на оваа истражувачка техника, истражувачот мора да предвиди на кој начин ќе се бележат резултатите добиени од анализата на содржина на изворите кои биле користени. Како што постојат раздични документи и извори, така и бележењето на фактите ќе биде раздично. Раздичното бележење ќе зависи и од тоа дали станува збор за квалитативни или квантитативни податоци.

За примена на техниката анадиза на содржината не постојат стандардизирани инструменти, но постојат некои општи методолошки барања и богати истражувачки искуства кои може да му бидат од голема помош на истражувачот. За секое проучување кое го организира, истражувачот мора сам да ги утврди инструментите за бележење на единиците на содржинска анализа. Многу е важно тоа бележење да биде прегледно, јасно, потполно, лесно за средување и обработка на собраните факти.

Во продолжение ќе наведеме некои можни начини и инструменти за бележење на фактите како единици на анализата на содржина.

При анализа на содржината на документи во пишана или на друг начин нотирана форма (диковна, филмска, информатички податоци), може да користиме раздични инструменти: табели, прегледи, регистри за податоци, чек листи и др.

Квалитативните факти (единици на анализата) најдобро се бележат на посебни листови, белешки, картици. Големината на евидентните листи зависи од големината и бројот на единиците на анализата на содржина. Доколку располагаме со квантитативни факти (единици на анадизата), тогаш може да се користат раздични табели и табеларни прегледи, чек-листи и слично. 
Постојат и компјутерски програми за анадиза на содржина на документите во педагошките истражувања, како што се: MaxQDa, NVivo, Atlas.ti. и други програми со чија помош може да се врши анадиза на податоците.

Ако е добро извршена критиката и категоризацијата на изворите и доколку со почитување на општите методолошки барања се утврдени критериумите за класификација на фактите, тогаш нема да биде тешко да се формудираат заклучоци и да се напише извештај за истражувањето. За можностите за примена на анализата на содржина сведочат и поголемиот број истражувања во нашата земја во кои техниката анализа на содржина е применета како основна или помошна техника за проучување на педагошките појави.

Во продолжение е презентиран пример на примена на анализата на содржина во конкретно педагошко истражување, каде предмет на анадиза се лектирните дела во основното образование.

\section{Анализа на содржина на дектирните дела по наставниот предмет Македонски јазик во првиот и вториот образовен цикдус на деветгодишното основно образование}

Анализа на содржината е применета во истражувањето „Користење на дитературните дела во наставата по Македонски јазик" при кое беше извршена квантитативна и квалитативна анализа на користењето на лектирните дела по наставниот предмет Македонски јазик во првиот и вториот образовен циклус на деветгодишното основно образование. (Јаневска, 2021)

За потребите на истражувањето, согласно дефинираните цели, задачи и истражувачки прашања беше конструиран инструмент за анализа на содржина во вид на чек-диста со релевантните аспекти на истражувањеTo.

1. Чек-листа за анализа на лектирните дела предвидени според програмата по наставниот предмет Македонски јазик од второ до шесто одделение

\begin{tabular}{|c|l|c|}
\hline $\begin{array}{c}\text { Реден } \\
\text { број }\end{array}$ & $\begin{array}{l}\text { Лектирно дело } \\
\text { Автор на дектирното дело }\end{array}$ & \\
\hline \multirow{4}{*}{2.} & Домашен автор & \\
\cline { 2 - 3 } & Странски автор & \\
\cline { 2 - 3 } & Народна проза & \\
\hline \multirow{2}{*}{2.} & Литературна форма & \\
\cline { 2 - 3 } & Поезија & \\
\cline { 2 - 3 } & Проза & \\
\hline
\end{tabular}




\begin{tabular}{|c|c|c|}
\hline \multirow[t]{5}{*}{3.} & Прозни дела & \\
\hline & роман & \\
\hline & бајки & \\
\hline & басни & \\
\hline & раскази & \\
\hline \multirow{3}{*}{4.} & Поетски дела & \\
\hline & епски песни & \\
\hline & лирски песни & \\
\hline \multicolumn{3}{|c|}{ Дитературни елементи } \\
\hline \multirow[t]{6}{*}{5.} & Тема & \\
\hline & од детскиот живот & \\
\hline & од семејниот живот & \\
\hline & реалистична & \\
\hline & фантастична & \\
\hline & историска & \\
\hline \multirow[t]{4}{*}{6.} & Насдов & \\
\hline & еден збор & \\
\hline & синтагма & \\
\hline & ист со темата & \\
\hline \multirow[t]{8}{*}{7.} & Докализација & \\
\hline & потесна & \\
\hline & поширока & \\
\hline & блиска за нас & \\
\hline & далечна за нас & \\
\hline & во град & \\
\hline & во село & \\
\hline & во природа & \\
\hline \multirow[t]{11}{*}{8.} & Фабула & \\
\hline & континуирана & \\
\hline & дисконтинуирана & \\
\hline & лесно разбирлива & \\
\hline & тешко разбирлива & \\
\hline & долга & \\
\hline & куса & \\
\hline & интересна & \\
\hline & здодевна & \\
\hline & бавна (развлечена) & \\
\hline & брза & \\
\hline \multirow[t]{3}{*}{9.} & Проблем & \\
\hline & има проблем & \\
\hline & нема проблем & \\
\hline
\end{tabular}




\begin{tabular}{|c|c|c|}
\hline \multirow[t]{5}{*}{10.} & Дикови - гдавни дикови & \\
\hline & деца & \\
\hline & возрасни & \\
\hline & позитивен лик & \\
\hline & негативен лик & \\
\hline 11. & $\begin{array}{l}\text { Какви се потенцијадите на делото } \\
\text { за етичко влијание на ученикот? }\end{array}$ & $\begin{array}{l}\text { - воопшто не е присутно } \\
\text { - малку е присутно } \\
\text { - многу е присутно }\end{array}$ \\
\hline 12. & $\begin{array}{l}\text { Какви се емоционалните } \\
\text { потенцијали на делото? }\end{array}$ & $\begin{array}{lllll}1 & 2 & 3 & 4 & 5\end{array}$ \\
\hline 13. & $\begin{array}{l}\text { Колку делото побудува кај децата } \\
\text { интерес за читање? }\end{array}$ & $\begin{array}{l}\text { - воопшто не е присутно } \\
\text { - малку е присутно } \\
\text { - многу е присутно }\end{array}$ \\
\hline
\end{tabular}

\section{Резултати}

Според податоците добиени од анализата на карактеристиките на лектирните дела од првите два образовни циклуси може да се заклучи дека бројот на домашните и странските автори е речиси изедначен. Од вкупно 55 лектирни дела, 28 се од домашен автор, 25 се од странски автор. Тоа дава можности учениците да се запознаат со домашното, но и со странското литературно творештво.

Забележителна е релативно малата застапеност на поетските лектирни дела во однос на прозните лектирни дела, 10 респективно 43. Во првите два образовни циклуси од основното образование најзастапени се романите, 25. Најмногу се застапени во шесто одделение, дури 9 или 36 \% од вкупниот примерок на лектирни дела. Во првите четири одделенија бројот на лектирните дела во форма на романи е повеќе од двојно помал во однос на нивната застапеност во петто и шесто одделение. Ваквиот сооднос има логична поставеност, бидејќи токму во овие две одделенија доаѓа до усложнување на наставните цели по наставниот предмет Македонски јазик. Евидентно е дека не постои некоја закономерност во застапеноста на дирските песни на одлелните степени. Процентуалната застапеност на овој вид на поезија е најголема во однос на сите други видови поетски творби, а истата е со идентичен број во второ и во шесто одделение, претставена со по две збирки од лирски песни.

При анализата на литературните елементи во лектирните дела во однос на темата, добиени се резултати според кои во генерални рамки може да се заклучи дека најголем број од темите се однесуваат на животот на децата $(57,78 \%$ и и на семејниот живот $(17,78$ \%), со што може да се заклучи дека 3/4 од темите се од непосредниот живот и од окодината во која живеат децата. Темите се реалистични, дури 44,44 \%, при што не е забележана закономерност. Фантастичните теми се застапени со 55,6 \%, со најголема 
застапеност од 36 \% во петто одделение, а процентот на фантастичните теми во шесто одделение опаѓа на $16 \%$.

Поголем дел од дејствијата според анализата на локализацијата се одвиваат на подалечни локализации, а нешто помалку од половина од дејствијата во лектирните дела се одвиваат во детската блиска окодина. Не се сигнификантни раздиките во однос на дејствијата што се одвиваат во град и во природата, 48,89\%, респективно 42,22 \%.

Во сите лектирни дела фабулата е континуирана и лесно разбирлива, со исклучок на две лектирни дела во кои фабулата е потешка за разбирање. Таа најчесто е долга, што е разбирливо бидејќи најзастапена форма кај лектирните дела е романот. Според направената проценка сите лектирни дела се интересни за читање, а 19 лектирни дела или 42,22 \% имаат брзи дејствија. Триесет и шест лектирни дела, односно 80 \% од нив се податливи за проблемска анализа.

При анализата на ликовите во лектирните литературни дела забележлив е рамномерниот распоред на ликови од раздична возраст, при што, според истражувачот најголем дел од ликовите 43 или 95,56 \% се окарактеризирани како позитивни ликови. Ваквата распределеност е сосема разбирлива доколку се земе предвид дека младите читатели се идентификуваат со позитивните ликови.

Според ова може да се заклучи дека лектирните дела имаат воспитни потенцијали за позитивно влијание врз учениците.

Емоционалните потенцијали на лектирните дела се вреднувани од страна на истражувачот, со цел да се испита можноста за нивно вдијание врз емоционалниот развој на учениците, како и емоционалното доживување воопшто, која се развива при читањето на одделни лектирни дела.

Скалата за процена е изразена нумерички со оценки од 1 до 5, каде 1 претставува најниска оценка, а 5 највисока оценка. Оценката 1 означува дека читањето на лектирното дело кај ученикот/ученичката не побудува никакви чувства, не поттикнува емпатичност и поистоветување со главниот лик од делото. Оценката 2 означува слабо, незначително влијание на содржината од делото врз емоциите кај ученикот/ученичката што го чита. Со оценката 3 се карактеризира содржината која преку нејзино читање побудува одредени емоции кај учениците и поттикнува на размислување како ликот понатаму ќе се однесува, чувствувајќи ги тие емоции. Со оценката 4 се карактеризира содржината од лектирното дело која побудува поизразени чувства и развива поголема емпатија кон дикот и неговите дејствија. Со оценката 5 се карактеризира содржината која врз учениците има најголемо емоционално влијание и тие размислуваат преку проектирање на истата прочитана ситуација. 


\section{Табела 1}

Анализа на емоционалните потенцијали на лектирните дела во првиот и вториот образовен цциклус

\begin{tabular}{|c|r|r|r|r|r|c|}
\hline \multirow{2}{*}{$\begin{array}{c}\text { Оценка за емоцио-- } \\
\text { налната вредност } \\
\text { на дектирата }\end{array}$} & $\begin{array}{c}\text { второ } \\
\text { одде- } \\
\text { пение }\end{array}$ & $\begin{array}{c}\text { трето } \\
\text { одде- } \\
\text { пение }\end{array}$ & $\begin{array}{c}\text { четврто } \\
\text { одделе- } \\
\text { ние }\end{array}$ & $\begin{array}{c}\text { петто } \\
\text { одделе- } \\
\text { ние }\end{array}$ & $\begin{array}{c}\text { шесто } \\
\text { одде- } \\
\text { пение }\end{array}$ & \\
\hline 1 & 0 & 0 & 0 & 0 & 0 & 0 \\
\hline 2 & 1 & 0 & 0 & 0 & 0 & 1 \\
\hline 3 & 1 & 2 & 1 & 0 & 4 & 8 \\
\hline 4 & 1 & 3 & 7 & 7 & 4 & 22 \\
\hline 5 & 3 & 4 & 3 & 7 & 7 & 24 \\
\hline Вкупно & 6 & 9 & 11 & 14 & 15 & 55 \\
\hline Просечна оценка & 4,00 & $\mathbf{4 , 2 2}$ & $\mathbf{4 , 1 8}$ & $\mathbf{4 , 5 0}$ & $\mathbf{4 , 2 0}$ & $\mathbf{4 , 2 2}$ \\
\hline
\end{tabular}

Од добиените податоци може да се види дека лектирните дела имаат многу високи емоционални потенцијали, бидејќи најмалата средна оценка е 4,00 и се однесува на лектирните дела за второ одделение, а највисоката оценка изнесува 4,50 и се однесува на лектирите за петто одделение. Тоа значи дека за лектирни дела се избрани литературни дела со високи емоционални потенцијали. Просечната оценка за емоционалните потенцијали на сите лектирни дела од второ до шесто одделение изнесува 4,22, што е изразено висока вредност на скалата од 1 до 5.

Во согласност со овој резултат е и фактот што при анадизата на етичките вредности на лектирните дела, дури 47 од нив или 85,45 \% се многу податливи за етичко вреднување. Преку овие резултати може да се заклучи дека лектирните дела имаат воспитни потенцијали и позитивно влијаат врз учениците.

Во процесот на вреднување на етичките аспекти на лектирите дела, се оценуваше дали лектирното дело развива кај ученикот вредности за правилно, добро однесување, му укажува како да ги раздикува добрите од иошите постапки, му помага да ги открива позитивните особини и добрите постапки на ликовите од делото, да се поистоветува со нив и истите да ги применува, а лошите, неправилните, несоодветните и здите да ги критикува, отфрла и осудува. Скалата за проценка е изразена со атрибутивни категории, како што се категориите: „воопшто не е присутно“, „малку е присутно“ и „многу е присутно“.

Со категоријата „воопшто не е присутно“ се означува дека при читањето на лектирното дело кај ученикот/ученичката не се побудуваат никакви чувства, не се поттикнува емпатија и поистоветувањето со главниот дик од делото. Со зборот „малку е присутно“ се вреднува содржината која преку нејзино читање би побудила барем некои правилни постапки кај 
учениците и би ги поттикнало на размислување како ликот понатаму би можел да се однесува. Со атрибутот „многу е присутно“ се вреднува содржината која врз учениците има најголемо етичко вдијание, тие критички размислуваат и заземаат став преку проектирање на истата прочитана ситуација.

\section{Заклучок}

Во современото значење и облик, анализата на содржина има голем потенцијал за примена во проучување на педагошките феномени, но и за примена во секојдневната воспитно-образовна работа во училиштето и вонучидишните активности. Во голем дел педагошки истражувања се јавува како основна техника за собирање на податоци, но уште повеќе доаѓа до израз кога е применета во комбинација со други истражувачки техники како скалирање, интервјуирање, тестирање.

Во применетото истражување анализата на содржина е користена како примарна техника за вреднување на лектирните дела предвидени во наставниот предмет Македонски јазик во првите два образовни циклуси од основното воспитание и образование. Резултатите покажуваат дека се користат лектирни дела од домашни и странски автори со раздична жанровска и родовска припадност. Делата имаат изразен потенцијал за емоционално и етичко влијание врз учениците, иако постои извесна утврдена раздика во нивната присутност и застапеност во раздичните одделенија. 
Питература

АНГЕЛОСКА-ГАЯЕВСКА, Наташа (1998). Квалитативни истражувата во воспитанието и образованието. Битола: Киро Дандаро.

БЕРЕЛСОН, Бернард (1995). „Анализа садржаја”, Пејчић, Б. (ур.), Методологија емпиријског научног истраживаюа. Београд: Дефектолошки факултет.

ГРЕДЕД, Стјепан (1986). С ону страну огледала. Београд: Истраживачко издавачки центар ССО Србије.

JAHEBCKA, Маја (2021). Користенье на литературните дела во наставата по Македонски јазик. Скопје: Филозофски факултет.

НАСТАВНА ПРОГРАМА ПО МАКЕДОНСКИ ЈАЗИК ЗА І ОДДЕДЕНИЕ ВО ДЕВЕТГОДИШНОТО ОСНОВНО ОБРАЗОВАНИЕ. (2007). Скопје: Биро за развој на образованието.

НАСТАВНА ПРОГРАМА ПО МАКЕДОНСКИ ЈАЗИК ЗА ІІ ОДДЕЛЕНИЕ ВО ДЕВЕТГОДИШНОТО ОСНОВНО ОБРАЗОВАНИЕ. (2007). Скопје: Биро за развој на образованието.

НАСТАВНА ПРОГРАМА ПО МАКЕДОНСКИ ЈАЗИК ЗА ІІІ ОДДЕДЕНИЕ ВО ДЕВЕТГОДИШНОТО ОСНОВНО ОБРАЗОВАНИЕ. (2007). Скопје: Биро за развој на образованието.

НАСТАВНА ПРОГРАМА ПО МАКЕДОНСКИ ЈАЗИК ЗА ІV ОДДЕДЕНИЕ ВО ДЕВЕТГОДИШНОТО ОСНОВНО ОБРАЗОВАНИЕ. (2007). Скопје: Биро за развој на образованието.

НАСТАВНА ПРОГРАМА ПО МАКЕДОНСКИ ЈАЗИК ЗА V ОДДЕДЕНИЕ ВО ДЕВЕТГОДИШНОТО ОСНОВНО ОБРАЗОВАНИЕ. (2007). Скопје: Биро за развој на образованието.

НАСТАВНА ПРОГРАМА ПО МАКЕДОНСКИ ЈАЗИК ЗА VІ ОДДЕЯЕНИЕ ВО ДЕВЕТГОДИШНОТО ОСНОВНО ОБРАЗОВАНИЕ. (2007). Скопје: Биро за развој на образованието.

BERELSON, Bernard (1952). Content Analysis in Communication Research. New York: Free Press.

BUSHA, Charles H. \& HARTER, Stephen P. (1980). Research Methods in Librarianship: Techniques and Interpretation. New York: Academic Press.

DE SOLA POOL, Ithiel. (1959). Trends in Content Analysis. Urbana: University of Illinois Press, 1959.

KRIPPENDORFF, Klaus. (1980). Content Analysis: An Introduction to its Methodology. Beverly Hills: Sage Publications. 